\title{
Influence of Cellulolytic Bacterial Augmentation on Organic Carbon and Available Phosphorus in Sandy Loam Soil under Cultivation
}

\author{
Machiavelli Singh \\ Department of Biotechnology and Environmental Sciences \\ Thapar University, Patiala, India \\ E-mail: machiavellisingh@gmail.com \\ Suneel Khanna \\ Department of Biotechnology and Bioinformatics \\ NIIT University, Neemrana, Rajasthan, India \\ E-mail: sunil.khanna@niituniversity.in \\ N.Tejo Prakash \\ Department of Biotechnology and Environmental Sciences \\ Thapar University, Patiala, India \\ Tel: 91-175-239-3318_E-mail: ntejoprakash@thapar.edu
}

The research is supported by a joint programme of United Nations Development Programme and Technology Information Forcasting Assessment Council, Government of India, New Delhi, India.

\begin{abstract}
Microorganisms are major key players for sustaining the soil quality degraded by intensive use of synthetic chemicals for increasing crop production and therefore, use of them as inoculants or biofertilizers is an integral part of sustainable agriculture. An effort was, therefore, made to examine the effect of cellulose degrading bacterial isolates on legume (Chickpea) based cropping systems. No chemical/organic fertilizer was added during this study. The bacterial isolates viz., Serratia sp. (MSK1 and MSK24) and Pseudomonas sp. (MSK13) exhibiting cellulase activity of 3.83, 4.21 and $4.52 \mathrm{mM}$ glucose $\mathrm{ml}^{-1} \mathrm{~h}^{-1}$ respectively were introduced as inoculants. The ERIC-PCR results showed the good survivability of introduced strains in soil, measured after crop harvest, respectively 40.2. 56.8 and $34.4 \%$. A significant enhancement in organic carbon and available phosphorus was observed in the inoculated plots over the control plot, indicating beneficial effect of the bioaugmentation of these inoculants.
\end{abstract}

Keywords: Agricultural soils, Phosphatase, Cellulase, Rhizobacteria, Survivability

\section{Introduction}

Soil is a dynamic, living matrix that is an essential part of the terrestrial ecosystem (Corstanje et al., 2007). It is a critical resource not only for agricultural production and food security but also towards maintenance of most life processes. The functions of soil biota are central to decomposition processes and nutrient cycling (Vikram et al., 2007). However, soils under intensive crop production are prone to organic matter losses that may result in reduced enzyme activity and microbial biomass, which bring about deterioration of the physic-chemical and biological condition (Haynes and Tregurtha, 1999).

Agricultural residues are a rich source of cellulose (Hameeda, 2006). As the main component of plant fiber structures, cellulose is arranged in crystalline to amorphous forms and is a substrate to numerous species of both fungi and bacteria relying on extracellular enzymes. Up until now, the most studied group of cellulose-degrading microorganisms is the fungi, which are characterized by multicomponent, synergistic cellulolytic enzyme systems (Eriksson et al., 1990; Berg and Laskowski, 2006). Although cellulose-decomposing bacteria are ubiquitous in soils, systematic studies on the structure and activities of cellulolytic communities are rare. Cellulases play an important role in carbon availability and so can be used to give a preliminary indication of some of the physical chemical properties of soil, thus, easing agricultural soil management strategies (Ndakidemi and Makoi, 2008). In 
soil ecosystems, phosphatases play a critical role in plant growth by enhancing the availability of phosphorus due to enhanced solubilisation and remobilisation of phosphate (Speir and Ross, 1978). Studies have shown that activity of these enzymes in agricultural soils are affected by several factors such as temperature, soil $\mathrm{pH}$, water and oxygen contents (abiotic conditions), the chemical characteristics of organic matter and its location in the soil profile horizon (Rubidge, 1977; Gomah, 1980; Tabatabai, 1982; Klein, 1989; Alf and Nannipieri, 1995). These findings suggest that activities of cellulases can be used to give a preliminary indication of some of the physical chemical properties of soil, thus, easing soil management strategies.

The present study, outlines: isolation, screening, characterization and identification of potential cellulose degrading bacteria and the use of their population dynamics as an index of organic fertility and nutritional status of soil.

\section{Materials and Methods}

\subsection{Sampling and analysis of soil}

Soil samples used for the isolation of cellulose degrading bacteria were collected from different chickpea (Cicer arietinum L.) agricultural fields of Patiala District, Punjab, India. Soil samples were collected randomly at from $0-30 \mathrm{~cm}$ of depth from nine different sites in one acre field by alcohol sterilized implements and stored in sterile containers. Three composites samples were prepared, air-dried and pulverized for organic carbon, nitrogen, available phosphorus, potassium, moisture level, texture and $\mathrm{pH}$ by following standard methods (Jackson, 1967).

\subsection{Determination of Soil Enzyme Activities}

The soil fertility was monitored by estimating two soil enzymes: cellulase (Bailey et al., 1985) and phosphatase (Tabatabai and Bremner, 1969) in soil taken at planting (0 week) and harvest $\left(16^{\text {th }}\right.$ week) time. Soils were processed the same day for microbial and enzymatic activities using standard protocols and stored at $4{ }^{\circ} \mathrm{C}$ for soil analysis.

Estimation of soil phosphatase activity was carried out by taking $10 \mathrm{~g}$ of soil in $4 \mathrm{ml}$ sterile universal buffer. $1 \mathrm{ml}$ of $0.115 \mathrm{M}$ disodium $p$-nitrophenyl phosphate was added and incubated in dark at $37^{\circ} \mathrm{C}$ for $2 \mathrm{~h}$, followed by an addition of $5 \mathrm{ml}$ of $0.5 \mathrm{~N}$ sodium hydroxide to stop the reaction. The reaction mixture was thoroughly mixed, filtered and filtrate was measured at $410 \mathrm{~nm}$. The phosphatase activity was expressed as $p$-nitrophenol (PNP) released per gram of soil i.e., $1 \mu \mathrm{m}$ of $\mathrm{PNP} / \mathrm{g}$ dry wt. soi/h. Soils were processed the same day for microbial and enzymatic activities using standard protocols and stored at $4^{\circ} \mathrm{C}$ for soil analysis. For estimating cellulose activity, $10 \mathrm{gm}$ of soil was suspended in $5 \mathrm{ml}$ of $0.05 \mathrm{M}$ phosphate buffer $(\mathrm{pH} 7.0) .0 .1 \mathrm{ml}$ of filtered suspension was taken to which $0.9 \mathrm{ml}$ of $1.0 \%$ carboxymethyl cellulose $(\mathrm{CMS})$ was added. The reaction mixture $(1.0 \mathrm{ml})$ was incubated at $37^{\circ} \mathrm{C}$ for $1 \mathrm{~h}$, followed by addition of $2 \mathrm{ml}$ dinitro salicylic acid (DNSA) reagent and further incubation of $15 \mathrm{~min}$ in boiling water bath. One unit of cellulase activity was defined as amount of enzyme necessary to release $1 \mu \mathrm{m}$ of glucose equivalent/min.

\subsection{Isolation and Enumeration of microbial population}

For isolation and enumeration of cultivable bacteria, soil samples were diluted in saline $(0.89 \% \mathrm{NaCl}$; w/v) solution and plated on soil extract agar for total microbial count, Pikovskaya agar (PA) for the isolation of phosphate solubilisers and Bushnell Hass Agar (BHA) supplemented with 1\% carboxy methyl cellulose (w/v) as sole source of carbon for cellulose degraders. Plated triplicates of three different dilutions $\left(10^{-5}\right.$ to $\left.10^{-7}\right)$ were incubated for $48 \mathrm{~h}$ at $37^{\circ} \mathrm{C}$ and colonies were counted (cfu g ${ }^{-1}$ dry wt. of soil).

\subsection{Screening of Cellulolytic Isolates}

Congo red was used as an indicator for the detection of cellulolytic activity on CM-cellulose-agar medium, as described by Teather and Wood (1982). Cellulolytic activity of isolates was evaluated according to the extent and intensity of the hydrolytic clearing zones. Bacterial isolates were grown in $50 \mathrm{ml}$ Bushnell Hass broth (BHB) with carboxymethyl cellulose $(1 \% ; \mathrm{w} / \mathrm{v})$ in 250 -ml flask and incubated on rotary shaker at $37^{\circ} \mathrm{C}, 120 \mathrm{rpm}$. After $72 \mathrm{~h}$, the cells were centrifuged $(9000 \mathrm{~g}, 10 \mathrm{~min})$ and supernatant was collected for enzyme assay. Cellulase (CMCase) activity was measured by the 3,5-dinitrosalicylic acid (DNS) method (Miller, 1959), through the determination of the amount of reducing sugars liberated from carboxymethyl cellulose $(\mathrm{CMC})$ solubilised in 50 $\mathrm{mM}$ Tris- $\mathrm{HCl}$ buffer (pH 7.0) (Baily et al., 1992). Enzyme assay was carried out at $37^{\circ} \mathrm{C}$ for $1 \mathrm{~h}$ and the reaction was stopped by the addition of DNS solution. Samples were then boiled for $10 \mathrm{~min}$, cooled on ice for color stabilization, and the optical density was measured at $540 \mathrm{~nm}$. Cellulase activity was determined by using a calibration curve for glucose and expressed as $\mu \mathrm{M}$ glucose $\mathrm{g}^{-1} \mathrm{~h}^{-1}$. 


\subsection{ERIC-PCR based fingerprinting of isolates}

Enterobacteriaceae Repetitive Intergenic Consensus - Polymerase Chain Reaction (ERIC-PCR) was carried out to obtain DNA fingerprints of the cellulose degraders. PCR primer sequences (Versalovic et al., 1991), ERIC IR $\left(5^{\prime}-3^{\prime}\right)$ - ATGTAAGCTCCTGGGGAATCAC- and ERIC - 2 (5' - $\left.3^{\prime}\right)$ AAGTAAGTGACTGGGGTGAGCG- were obtained from Life Technologies, USA. Single isolated colonies were picked at random from the LA plates, suspended in $50 \mu \mathrm{l}$ water, and lysed by heating for $10 \mathrm{~min}$ at $95^{\circ} \mathrm{C}$. Cell lysate was centrifuged $(9000 \mathrm{x} \mathrm{g}, 3 \mathrm{~min})$ at $4^{\circ} \mathrm{C}$, and $2 \mu 1$ of the supernatant was used in the reaction mixture. The reaction mixture $(25 \mu \mathrm{l})$ contained $10 \mathrm{mM}$ Tris- $\mathrm{HCl}(\mathrm{pH} 8.3), 50 \mathrm{mM} \mathrm{KCl}, 2.5 \mathrm{mM} \mathrm{MgCl} 2,0.01 \%$ gelatin (wt/vol), $0.25 \mathrm{mM}$ each of dNTPs, $0.375 \mu \mathrm{M}$ each of primers ERIC-1R and ERIC-2, and 2.0 units of Taq polymerase (Life Technologies, USA). The amplification was done on Genamp PCR system (Applied Biosystem, USA). The PCR conditions were as follows: initial denaturation at $94^{\circ} \mathrm{C}(4 \mathrm{~min})$ followed by 41 cycles at $94^{\circ} \mathrm{C}$ $(1 \mathrm{~min})$ then at $50^{\circ} \mathrm{C}(1 \mathrm{~min})$ and finally at $72^{\circ} \mathrm{C}(2 \mathrm{~min})$. The ultimate extension was done at $72^{\circ} \mathrm{C}(5 \mathrm{~min})$. The reaction was terminated by using a loading dye $(1 \mu \mathrm{l})$ containing Ficoll $15 \%$, bromophenol blue $0.25 \%$, and xylene cyanol $0.25 \%$. Each PCR product was resolved by electrophoresis on a $1.5 \%$ agarose gel.

\subsection{Plot studies}

Plot studies were conducted under sandy loam agricultural soil. Chemical composition of this soil was organic carbon, $0.78 \pm 0.03 \%$; total nitrogen, $0.0823 \pm 0.005 \%$; and available phosphorus $44.00 \pm 5.6 \mathrm{mg} / \mathrm{kg}$. Randomized design was adopted to study the degradation of cellulose in the agriculture soil by inoculating the most efficient cellulose degraders in plots $\left(4 \mathrm{~m}^{2}\right)$ sown with chickpea (Cicer arietinum L.) crop. Cultures were grown in 10 litre shake flasks containing Luria broth (LB) medium and incubated at $37^{\circ} \mathrm{C}$ with rotary shaking set at $120 \mathrm{rpm}$. After $36 \mathrm{~h}$, the cells were harvested and washed with $10 \mathrm{mM}$ phosphate buffer $(\mathrm{pH} 6.8)$. Pellets were resuspended in buffer and inoculated in plots at cell concentration of approximately $2 \times 10^{8} \mathrm{cfu} / \mathrm{g}$ soil. Control plot received only BHB without any bacterial cells. The prescribed package of practices (PAU, 2005) was followed and monitored during the cultivation of the chickpea. At 0 week (planting and inoculation time) and $16^{\text {th }}$ week after sowing (harvest time) soil samples were collected from different points, composite samples were prepared and taken in triplicate to evaluate the population dynamics and other soil parameters. One gram of soil was suspended in $9 \mathrm{ml}$ of sterilized saline water $(0.8 \% \mathrm{NaCl} ; \mathrm{w} / \mathrm{v})$ by vigorous vortexing followed by serial dilution. An aliquot of 100 $\mu \mathrm{l}$ was plated on LA containing ampicillin $(120 \mu \mathrm{g} / \mathrm{ml})$. Plates were incubated for $36 \mathrm{~h}$ at $37{ }^{\circ} \mathrm{C}$. Individual colonies obtained after this incubation were restreaked on LA plates containing ampicillin $(120 \mu \mathrm{g} / \mathrm{ml})$. Colonies grown were scored and their DNA was isolated for fingerprinting protocol based on ERIC-PCR.

\subsection{Data analysis}

Variance (ANOVA), regression and multiple comparison analysis were carried out at $\mathrm{p} \leq 0.05$, using COSTAT software.

\section{Results and Discussion}

Thirty-one cellulose degrading bacterial isolates were isolated from agricultural soils cultivated with chickpea (Figure 1). Three isolates, namely MSK1, MSK13 and MSK24 showed their high efficacy to degrade carboxy methyl cellulose (CMC) in plate assay. The values were: $3.83,4.21$ and $4.52 \mathrm{mM}$ glucose $\mathrm{ml}^{-1} \mathrm{~h}^{-1}$ respectively. These 3 strains were chosen for further morphological and biochemical characterisation (Table 1). MSK1, MSK13 and MSK24 were Gram negative, non-spore forming and positive to extracellular CMCase and xylanase activity. The optimum growth conditions for these isolates were $25-37^{\circ} \mathrm{C}$ at $\mathrm{pH}$ 6.0-8.0. MSK1 and MSK24 showed catalase positive, oxidase and nitrate reduction negative reaction, but MSK13 was catalase negative, oxidase positive and nitrate reduction positive. Antibiotic screening showed that MSK1, MSK13 and MSK24 were sensitive to norfloxacin, gentamicin, chloramphenicol, cefuroxime, ciprofloxacin, resistant to ampicillin. These isolates were identified by partial sequencing of $16 \mathrm{~S}$ rRNA, so homology search revealed that MSK1, MSK13 and MSK24 were 99\% similar to Serratia sp., Pseudomonas sp. and Serratia marcescens respectively (data not shown).

Investigations by other researchers showed that aerobic bacteria belonging to species of Pseudomonas, Bacillus and Cellulomonas, and anaerobe such as Clostridium have cellulolytic potential (Sindhu et al., 2001). Serratia marcescens EB 67 and Pseudomonas sp. CDB 35 have been shown to possess cellulolytic activity in the presence of crop residues (Hameeda et al., 2006). The residing microflora maintains the soil health and affects the agronomic parameters of the crops planted on those plots. Thus, farming management trials along with the inoculants enhance the growth and yield of the crops (Dickey et al., 1994). Cellulolytic soil bacteria had been studied in various soils under different land use systems with respect to the effect of environmental conditions on the abundance and decomposing activity (Hiroki and Watanabe, 1996; Dilly et al., 2001). All of these studies 
were mostly based on the estimates of population densities using agar plate techniques; with population dynamics and characterisation being rarely analyzed (Ulrich et al., 2008)

Survival of the microorganisms in the soil after their application is a deciding factor in the rate of degradation of carbon source (Ramos et al., 1991) which is observably assessed with confidence mainly with PCR based molecular techniques (Versalovic et al., 1991; Thiem et al., 1994; Weidmann-Al-Ahmad et al., 1994; Giovanni et al., 1999). Repetitive DNA sequences have been characterized primarily from Escherichia coli and Salmonella typhimurium. These sequences, referred to as enterobacterial repetitive intergenic consensus sequence (ERIC) or intergenic repeat units (IRUs), are 126-bp elements containing a highly conserved central inverted repeat and are located in extragenic regions (Versalovic et al., 1991). The analysis of this element by PCR-synthesized oligonucleotide has provided unique DNA fingerprints. It is reported that ERIC probes hybridized preferentially to genomic DNA from Gramnegative bacteria (Giovanni et al. 1999). In the present study, survival of the microorganisms was tracked with the ERIC-PCR based genomic DNA fingerprinting method. ERIC-PCR of the isolates in the present study showed 10 to 14 distinctly amplified bands with sizes ranging from $11,000 \mathrm{bp}$ to 100 bp (Figure 2). Although 16S rDNA sequence analysis showed that MSK1 and MSK24 to have close homology with Serratia sp., ERIC-PCR enabled to differentiate between these isolates. The populations of Serratia sp. MSK1, Pseudomonas sp. MSK13 and Serratia sp. MSK24 showing a survival of 40.2, 34.4 and $56.8 \%$ respectively after 16 weeks (Figure 3). The strains of Serratia sp. and Pseudomonas sp. were found to be stable at the end of 16 weeks in the treated plots which is presumed to be due to their adaptability to local soil environment from where these were isolated. Among all the three treatments tested, significantly high values of microbial count and soil enzyme activities were observed in plots inoculated with Serratia sp. compared to control (Table 2). It was observed that the conventional plate counting method resulted in lower rates of survival of these isolates (41\%) as compared to the survival rate obtained from PCR fingerprinting (58\%). In absence of proper control, mere decrease in antibiotic counts cannot be related to the survival of specific inoculated bacterial isolate in a complex environment like agricultural soil. This is expected since in natural environment several microorganisms have no specific-drug resistance (Nakaune et al. 1998; Mathew et al. 1999) and therefore are selected on ERIC-PCR fingerprinting. The results of investigation also support the hypothesis that indigenous isolates will results in greater adaptation to the system as well promote the microbial population and activities in the soil.

The modulations in the soil enzyme activity and nutritional properties influenced by the microbial inoculation were studied by examining the cellulase activity, phosphatase activity, organic carbon, total nitrogen content and available phosphorus in the experimental plots. Most of these parameters were observed and found to be enhanced with augmentation of inoculants in the plots in comparison to the control plot. The present study also indicated increase in availability of carbon and other nutrients assumed to be facilitated through enhanced enzyme activity. The increased phosphate activity in the soil drawn from the plots amended with Pseudomonas sp. MSK 13 could be related to the metabolic versatility of this microbial group that facilitates increasing activity of phosphatases when P is a limiting nutrient (Tadano et al., 1993). The plots treated with Serratia sp. MSK1, Pseudomonas sp. MSK13 and Serratia sp., MSK24 showed significantly enhanced soil cellulase activity of 7.51, 9.02 and 10.25 ( $\mu \mathrm{M}$ glucose $\mathrm{g}^{-1}$ dry wt. soil $\mathrm{h}^{-1}$ ) respectively, in comparison to control plots (Table 2), which also correlated with the increase in population of the cellulose degrading inoculants $\left(\mathrm{r}^{2}: 0.730\right)$. Similarly, an increase in soil phosphatase activity was also observed ranging from $0.858 \mu \mathrm{M} \mathrm{PNP} \mathrm{g}^{-1}$ dry wt. soil h${ }^{-1}$ in plots inoculated with Serratia sp. (MSK13) to $1.497 \mu \mathrm{M} \mathrm{PNP} \mathrm{g}^{-1}$ dry wt. soil $\mathrm{h}^{-1}$ in plots augmented with Serratia sp. (MSK24) (Table 4) correlating with the levels of available phosphorus (Table 5). A significantly high value of total nitrogen was observed in the plots inoculated with Serratia sp. MSK1, Pseudomonas sp. MSK13 and Serratia sp. MSK24 $(0.234 \%, 0.245 \%$ and $0.272 \%$ respectively) when compared to control (Table 3$)$. The increase in organic carbon also correlated with increase in cellulase activity $\left(\mathrm{r}^{2}: 0.916\right)$. The increased population of phosphate solubilisers showed the increased availability of available phosphorus significantly high as compared to the control plot, to $98.66 \mathrm{mg} / \mathrm{kg}, 96.66 \mathrm{mg} / \mathrm{kg}$ and $99.66 \mathrm{mg} / \mathrm{kg}$ in the Serratia sp. MSK1, Pseudomonas sp. MSK13 and Serratia sp. MSK24 inoculated plots respectively. Similar investigations have earlier shown that legumes secrete more phosphatise enzymes than cereal (Yadav and Tarafdar, 2001). This may probably be due to a higher requirement of $\mathrm{P}$ by legumes in the symbiotic nitrogen fixation process as compared to cereals. The maximum available potassium of $115.0 \mathrm{mg} / \mathrm{kg}$ and significant enhanced nitrogen of $0.27 \%$ was observed in the Serratia sp. MSK24 plot (Table 4). As reported by Sivaramaiah et al. (2007) the efficacy of Bacillus sp. to enhance nodulation, plant dry matter and grain yield on co-inoculation with rhizobia has also been reported for other legumes Bacterial strains isolated from the maize rhizosphere including Bacillus, Pseudomonas and Serratia were reported to improve the yield by $9-14 \%$ (Lalande et. al., 1989). Significant increase in the root dry mass of rapeseed was observed due to inoculation with Proteus, Klebsiella and Bacillus (Bertrand et. al., 2001). Considering the results 
of this study in addition to the previous observation, it may be suggested that mass inoculation of aerobic cellulolytic bacteria used in present investigation can be a useful tool to maintain soil fertility by increasing microbial activity to decompose organic matter in leguminous ecosystem.

\section{Conclusion and Recommendations}

- Thirty-one strains were isolated from chickpea cultivated soils.

- Three of the isolates: MSK1, MSK13 and MSK24, showed higher efficacy to degrade carboxy methyl cellulose in plates.

- $\quad$ 16S rDNA sequence analysis and fingerprint method (ERIC-PCR) allowed identifying three species: Serratia sp. (MSK1), Pseudomonas sp. (MSK13) and Serratia sp. (MSK24), 99\% close to Serratia marcescens.

- A significant enrichment in organic carbon and available phosphorus was observed in the inoculated plots over the control plot indicating beneficial effect of the bioaugmentation of these inoculants.

The local isolates of both Serratia sp. and Pseudomonas sp. could be mass produced as a biological agent towards magnification of microbial diversity and soil organic carbon. Moreover, the introduction of such bacteria in chickpea soils, or cultural practices aims to increase the activity of native strains of these bacteria and they could greatly contribute to the efficiency of soil organic matter and the cellulolytic potential of soil bacterial communities as major contributors towards sustainable agriculture. Also, the rhizobacteria from the local rhizosphere soil could be exploited for use as microbial inoculants to improve nodulation (in legumes) and crop productivity of both cereals as well as legumes. Although potential clearly exists for developing such inoculants, their widespread application remains limited by a poor understanding of microbial ecology and population dynamics in soil; these studies are needed.

\section{References}

Alf, K. \& Nannipieri, P. (1995). Enzyme Activities, In K. Alf \& P. Nannipieri (Eds.), Methods in Applied Soil Microbiology and Biochemistry, ( pp. 311-373). London: Academic Press.

Bailey, M.J., Biely, P. \& Poutanen, K. (1992). Inter-laboratory testing of methods for assay of xylanase activity. Journal of Biotechnology, 23, 257-270.

Berg, B. \& Laskowski, R. (2006). Litter decomposition: a guide to carbon and nutrient turnover. Advances in Ecological Research Vol. 38. San Diego, CA: Elsevier Academic Press.

Bertrand, H., Nalin, R., Bally, R. \& Cleyet-Marel, J. C. (2001). Isolation and identification of the most efficient plant growth promoting bacteria associated with canola (Brassica napus). Biology and Fertility of Soils, 33, $152-156$.

Corstanje, R., Reddy, K.R., Prenger, J.P., Newman, S. \& Ogram, A.V. (2007). Soil microbial eco-physiological response to nutrient enrichment in a sub-tropical wetland. Ecological Indicators, 7, 277-289.

Dickey, E.C., Jasa, P. J. \& Grisso, R.D. (1994). Long term tillage effects on grain yield and soil properties in a soybean/grain sorghum rotation. Journal of Production Agriculture, 7, 465-470.

Dilly, O., Bartsch, S., Rosenbrock, P., Buscot, F. \& Munch, J.C. (2001). Shifts in physiological capabilities of the microbiota during the decomposition of leaf litter in a black alder (Alnus glutinosa (Gaertn.) L.). forest.. Soil Biology and Biochemistry, 33, 921-930.

Eriksson, K.E.L., Blancbette, R.A. \& Ander, P. (1990). Biodegradation of cellulose. In K.E.L. Eriksson, R.A. Blanchette \& P. Ander (Eds.), Microbial and enzymatic degradation of wood and wood components (pp. 89-180). New York: Springer-Verlag.

Giovanni, G.D.D., Watrud, L.S., Seidler, R.J. \& Widmer, F. (1999). Comparison of parental and transgenic alfalfa rhizosphere bacterial communities using Biolog GN metobolic fingerprinting and enterobacterial repetitive intergenic consensus sequence-PCR (ERIC-PCR). Microbial Ecology, 37, 129-139.

Gomah, A.M. (1980). Cellulase activity in soil as affected by addition of organic material, temperature, storage and drying and wetting cycles. Zeitschrift fuer Pflanzenernaehrung und Bodenkunde, 143, 349-356.

Hameeda, B., Reddy, H.K.Y., Rupela, O.P., Kumar, G.N. \& Reddy, G. (2006). Effect of carbon substrates on rock phosphate solubilization by bacteria from composts and macrofauna. Current Microbiology, 53, 298-302.

Haynes, R. J. \& Tregurtha, R. (1999). Effects of increasing periods under intensive arable vegetable production on biological, chemical and physical indices of soil quality. Biology and Fertility of Soils, 28, 259-262.

Hiroki, M. \& Watanabe, M.M. (1996). Microbial community and rate of cellulose decomposition in peat soils in 
a mire. Soil Science and Plant Nutrition, 42, 893-903.

Jackson, M. L. (2005). Soil chemical analysis. University of Wisconsin-Madison Parallel Press.

Klein, D.A. (1989). Cellulose functions in arid soil development. Arid Soil Research and Rehabilitation, 3, 185-198.

Lalande, R., Bissonnette, N., Countlee, D. \& Antoun, H. (1989). Identification of rhizobacteria from maize and determination of their plant growth promoting potential. Plant and Soil, 115, 7-11.

Mathew, A.G., Saxon, A.M., Upchurchand, W.G. \& Chattin, S.E. (1999). Multiple antibiotic resistance pattern of Escherichia coli isolates from swine farms. Applied and Environmental Microbiology, 65, 2770-2772.

Miller, G.L. (1959). Use of dinitrosalycilic acid reagent for determination of reducing sugar. Analytical Chemistry, 31, 426-428.

Nakaune, R., Adachi, K., Nawata, O., Tomiyama, M., Akutsu, K. \& Hibi, T. (1998). A novel ATP-binding cassette transporter involved in multidrug resistance in phytopathogenic fungus Penicillium digitatum. Applied and Environmental Microbiology, 64, 3983-3988.

Ndakidemi, P.A. \& Makoi, J.R. (2008). Selected soil enzymes: Examples of their potential roles in the ecosystem. African Journal of Biotechnology, 7, 181-191

Punjab Agricultural University. (2005). Package of practices for crops of Punjab-Rabi. 2005-06 (p.147), Punjab Agricultural University, Ludhiana.

Ramos, J.1., Duque, E. \& Ramos-Gonzalez, M.I. (1991). Survival in soils of an herbicide-resistant Pseudomonas putida strain bearing a recombinant TOL plasmid. Applied and Environmental Microbiology, 57, 260-266.

Rubidge, T. (1977). The effect of moisture content and incubation temperature upon the potential cellulase activity of John Innes no. 1 soil. International Biodeterioration Bulletin, 13, 39-44.

Sindhu, S.S. \& Dadarwal, K.R. (2001). Chitinolytic and cellulolytic Pseudomonas sp. antagonistic to fungal pathogens enhances nodulation by Mesorhizobium sp. Cicer in chickpea. Microbiological Research, 156, $353-358$.

Sivaramaiah, N., Malik, D.K. \& Sindhu, S.S. (2007). Improvement in symbiotic effi ciency of chickpea (Cicer arietinum L.) by coinoculation of Bacillus strains with Mesorhizobium sp. Cicer. Indian Journal of Microbiology, $47,51-56$.

Speir, T.W. \& Ross, D.J. (1978). Soil phosphatase and sulphatase. In R.G. Burns (Ed.) Soil Enzymes (pp. 197-250), London: Academic Press.

Tabatabai, M.A. (1982). Soil enzyme. In A.L.Page (Ed.) Methods of soil analysis, Part 2 (pp. 903-948), Madison: American Society of Agronomy.

Tabatabai, M.A. \& Bremner, J.M. (1969). Use of p-nitrophenyl phosphate for assay of soil phosphatase activity. Soil Biology and Biochemistry, 1, 301-307.

Tadano, T., Ozowa, K., Satai, M., Osak, M. \& Matsui, H. (1993). Secretion of acid phosphatase by the roots of crop plants under phosphorus deficient conditions and some properties of the enzyme secreted by lupine roots. Plant and Soils, 156, 95-98.

Teather, R.M. \& Wood, P.J. (1982). Use of Congo Red-polysaccharide interactions in enumeration and characterization of cellulolytic bacteria from bovine rumen. Applied and Environmental Microbiology, 43, 777-780.

Thiem, S.M., Krumme, M.L., Smith, R.L. \& Tiedje, J.M. (1994). Use of molecular tools to evaluate the survival of a microorganism injected into an aquifer. Applied and Environmental Microbiology, 60, 1059-1067.

Ulrich, A., Klimke, G. \& Wirth, S. (2008). Diversity and activity of cellulose-decomposing bacteria, isolated from a sandy and a loamy soil after long-term manure application. Microbial Ecology, 55, 512-522.

Versalovic, J., Koeuth, T. \& Lupski, J.R. (1991). Distribution of repetitive DNA sequences in eubacteria and application to fingerprinting of bacterial genomes. Nucleic Acids Research, 24, 6823-6831.

Vikram, A., Krishnaraj, P.U., Hamzezarghani, H. \& Jagadeesh, K.S. (2007). Growth promotional potential of Pseudomonas fluorescens FPD 10 and its interaction with Bradyrhizobium sp. Research Journal of Microbiology, 2, 354-361.

Weidmann-Al-Ahmad, M., Tichy, H.V. \& Schon, G. (1994). Characterization of Acinetobacter type strains and 
isolates obtained from wastewater treatment plants by PCR fingerprinting. Applied and Environmental Microbiology, 60, 4066-4071.

Yadav, R.S. \& Tarafdar, J.C. (2001). Influence of organic and inorganic phosphorous supply on the maximum secretion of acid phosphatase by plants. Biology Fertility of Soils, 34, 140-143.

Table 1. Biochemical characterization of the screened bacterial isolates from agricultural soils

\begin{tabular}{lccc}
\hline Character & MSK1 & MSK13 & MSK24 \\
\cline { 2 - 4 } Colony morphology & White & Creamy Yellow & Pinkish White \\
Gram stain & - & - & - \\
Spore & - & - & - \\
Catalase & + & - & + \\
Oxidase & - & + & - \\
Nitrate reduction & - & + & - \\
Growth at $25-37^{\circ} \mathrm{C}$ & + & + & + \\
Growth at pH 6-8 & + & + & + \\
CMCase & + & + & + \\
Xylanase & + & + & + \\
Ampicillin & $\mathrm{R}$ & $\mathrm{R}$ & $\mathrm{R}$ \\
Tetracyclin & $\mathrm{S}$ & $\mathrm{S}$ & $\mathrm{S}$ \\
Gentamycin & $\mathrm{S}$ & $\mathrm{S}$ & $\mathrm{S}$ \\
Kanamycin & $\mathrm{S}$ & $\mathrm{S}$ & $\mathrm{S}$ \\
\hline
\end{tabular}

+: positive reaction; -: negative reaction; R: Resistant at $120 \mu \mathrm{g}$; S: Sensitive

Table 2. Microbial populations and soil enzyme activities in soils of chickpea plot. Cellulose degraders count, Phosphate solublisers count, Cellulase and phosphatase activity were determined at 0 week (Chickpea sowing stage) and 16 weeks (Chickpea harvest stage) in soils

\begin{tabular}{|c|c|c|c|c|c|c|c|c|}
\hline \multirow[t]{2}{*}{ Treatment } & \multicolumn{2}{|c|}{$\begin{array}{l}\text { cellulose degraders } \\
\text { ( cfu x } 10^{6} \text { / g dry wt soil) }\end{array}$} & \multicolumn{2}{|c|}{$\begin{array}{l}\text { phosphate solubilisers } \\
\text { ( cfu x } 10^{6} \text { / g dry wt soil) }\end{array}$} & \multicolumn{2}{|c|}{$\begin{array}{l}\text { cellulase activity } \\
\text { (um glucose / g dry wt soil/ hr) }\end{array}$} & \multicolumn{2}{|c|}{$\begin{array}{l}\text { phosphatase activity } \\
\text { (um pnp / g dry wt soil/ hr) }\end{array}$} \\
\hline & $0 \mathrm{WEEK}$ & 16 WEEK & 0 WEEK & 16 WEEK & $0 \mathrm{WEEK}$ & 16 WEEK & 0 WEEK & 16 WEEK \\
\hline Control & $10.04 \pm 0.93 \mathrm{a}$ & $32.61 \pm 2.57 \mathrm{~b}$ & $13.00 \pm 0.96 \mathrm{a}$ & $26.76 \pm 1.43 b$ & $0.784 \pm 0.048 b$ & $4.489 \pm 0.322 \mathrm{~d}$ & $0.167 \pm 0.004 \mathrm{a}$ & $0.554 \pm 0.016 \mathrm{c}$ \\
\hline Serratia sp. MSK1 & $9.64 \pm 1.56 \mathrm{a}$ & $56.11 \pm 6.64 \mathrm{a}$ & $17.09 \pm 1.28 \mathrm{a}$ & $40.37 \pm 5.41 \mathrm{ab}$ & $1.404 \pm 0.102 \mathrm{a}$ & $7.518 \pm 0.392 \mathrm{c}$ & $0.171 \pm 0.004 \mathrm{a}$ & $0.662 \pm 0.019 b$ \\
\hline Pseudomonas sp MSK13 & $10.88 \pm 0.88 \mathrm{a}$ & $58.64 \pm 6.83 \mathrm{a}$ & $14.09 \pm 2.10 \mathrm{a}$ & $44.99 \pm 4.38 \mathrm{ab}$ & $1.287 \pm 0.013 \mathrm{a}$ & $9.026 \pm 0.233 b$ & $0.161 \pm 0.013 \mathrm{a}$ & $0.711 \pm 0.041 \mathrm{ab}$ \\
\hline Serratia sp. MSK24 & $12.87 \pm 1.41 \mathrm{a}$ & $73.58 \pm 6.35 \mathrm{a}$ & $14.37 \pm 0.71 \mathrm{a}$ & $53.14 \pm 6.28 b$ & $1.279 \pm 0.080 \mathrm{a}$ & $10.251 \pm 0.391 \mathrm{a}$ & $0.157 \pm 0.009 \mathrm{a}$ & $0.836 \pm 0.045 \mathrm{a}$ \\
\hline
\end{tabular}

Data characterized by the same letter are not significantly different $(\mathrm{p} \leq 0.05)$ in the rows. Above table represents Mean \pm Standard error of mean (SEM). 
Table 3. Soil nutritional status of chickpea plot. Organic carbon (OC), Nitrogen (N), Carbon/Nitrogen ratio (C/N), Available phosphorus ( $\mathrm{P}$ ) and Available potassium (K) were determined at 0 week (Chickpea sowing stage) and 16 weeks (Chickpea harvest stage) in soils

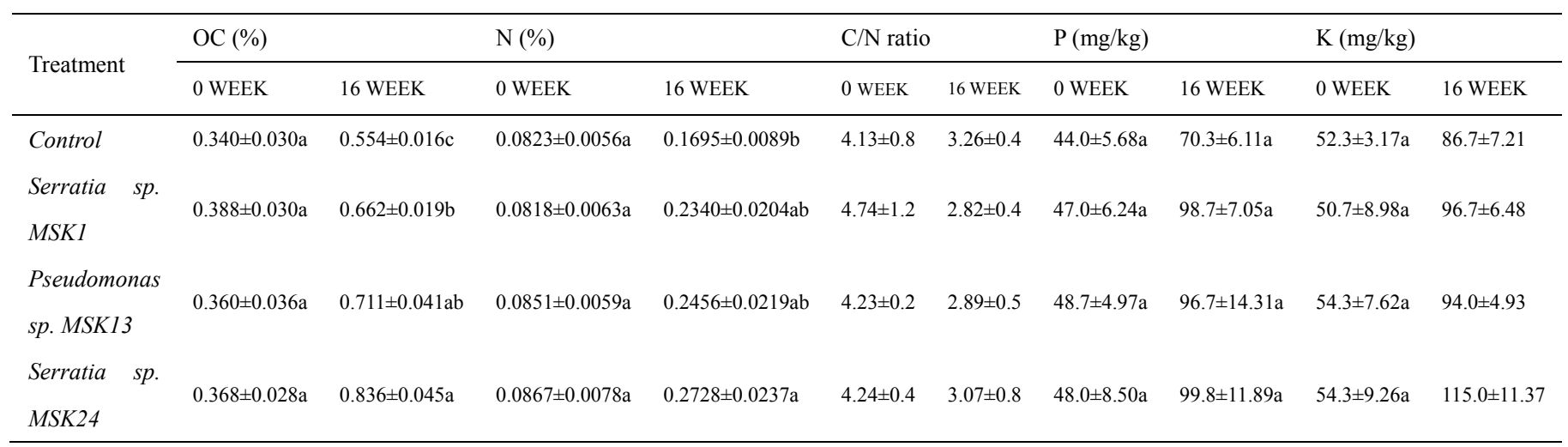

Data characterized by the same letter are not significantly different in the rows. Above table represents Mean \pm Standard error of mean (SEM)

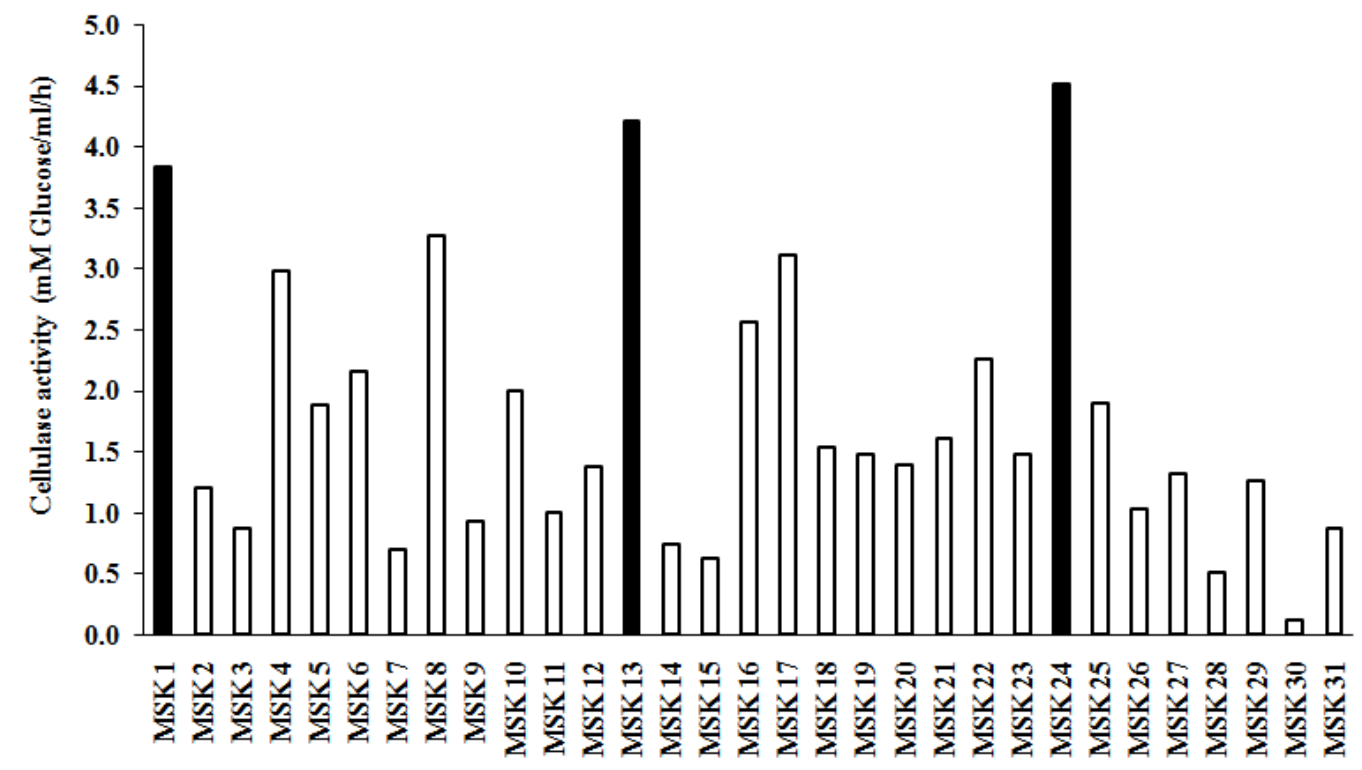

Isolates

Figure 1. Screening of isolates for Cellulase (CMCase) activity from agricultural soils 


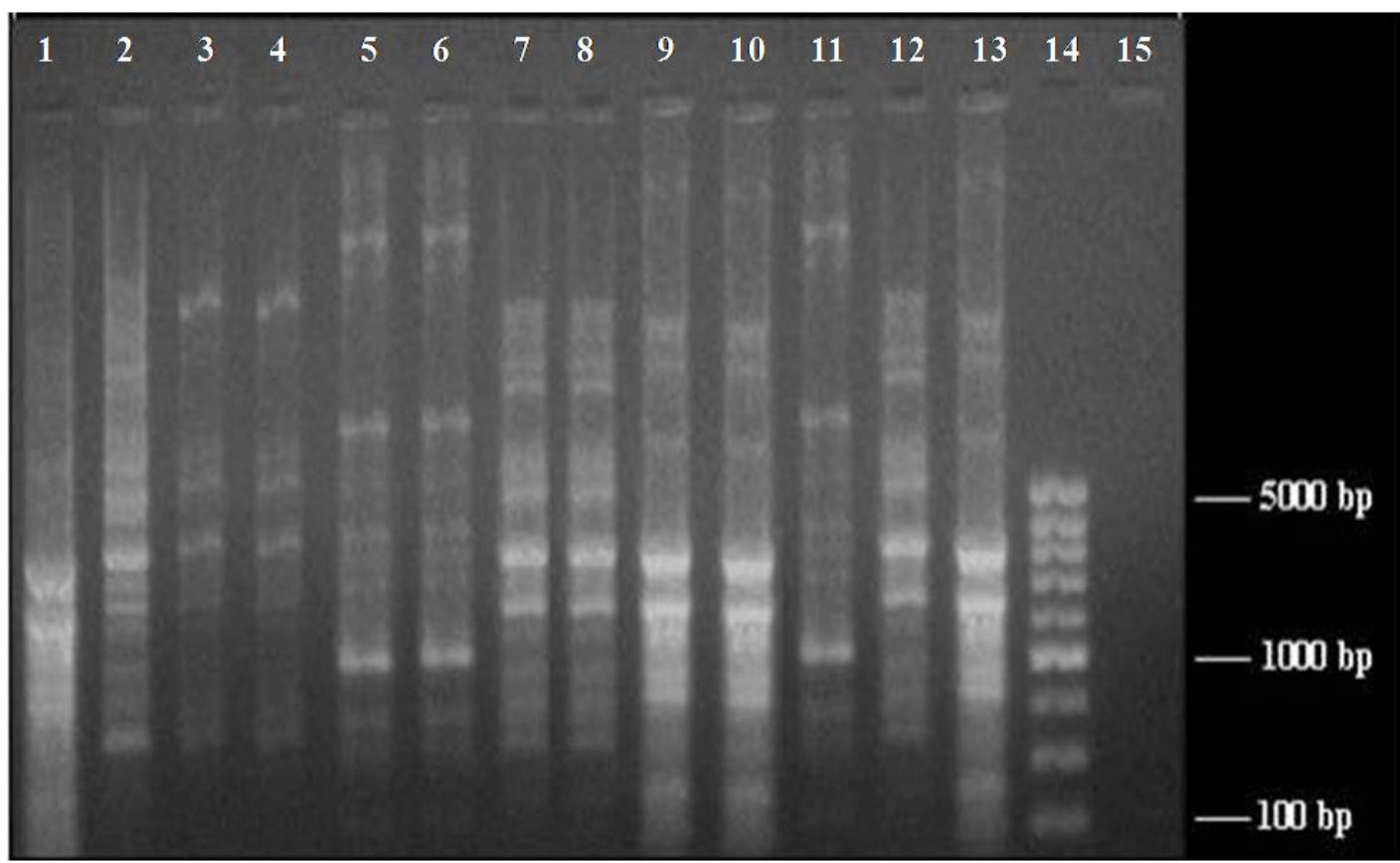

Figure 2. ERIC-PCR fingerprint of unknown bacterial isolates on 1.5\% agarose gel. Bacterial colonies were isolated from soil in the plots. Pure colonies were picked, heat lysed, and whole genomic DNA was subjected to ERIC-PCR to get the fingerprint.

Lanes 1-10: fingerprints of different isolates obtained from selected plates containing $120 \mu \mathrm{g} / \mathrm{ml}$ of Ampicillin

Lane 11: Standard bacterial strain of Pseudomonas sp. MSK13

Lane 12: Standard bacterial strain of Serratia sp. MSK1

Lane 13: Standard bacterial strain of Serratia sp. MSK24

Lane 14: 500bp ladder

Lane 15: Negative Control.

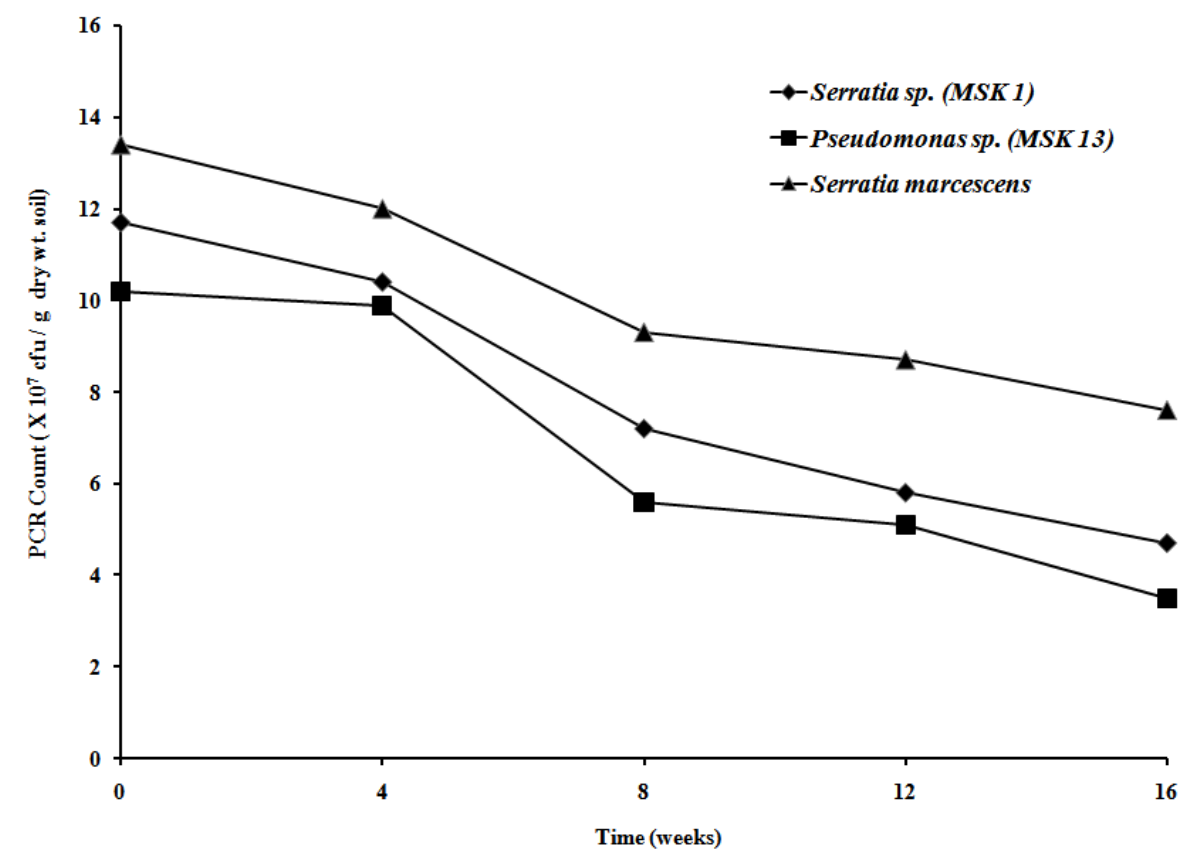

Figure 3. Survival of introduced bacterial strains during growing chickpea crop in plots 